\title{
Diagnosis of Coeliac Disease in Retrospect
}

\author{
ALEXANDER S. McNEISH \\ From the Royal Hospital for Sick Children, Oakbank, Glasgow
}

There are today a number of children who were originally diagnosed as having coeliac disease by criteria that we should now regard as inadequate. Almost all of these are receiving a gluten-free diet.

It is clearly of importance to substantiate the diagnosis, since current concepts of coeliac disease demand strict and prolonged dietary control, lasting at least until after the pubertal growth spurt (Hubble, 1963), and possibly to be followed for an indefinite period by regular haematological and biochemical screening procedures.

The cardinal diagnostic feature of untreated coeliac disease is the presence of mucosal villous atrophy in the upper small intestine (Creamer, 1966). In children these histological abnormalities improve considerably when gluten is withdrawn, and the mucosa may then return completely to normal (Anderson, 1960).

It is the purpose of the present paper to show that reintroduction of gluten into the diet for a short period, followed by jejunal biopsy, can separate coeliac from non-coeliac subjects in a group where the original diagnosis is in question.

\section{Patients and Methods}

Twenty-three children were studied, of whom 15 were girls. Their ages ranged from $5+$ to 13 years. The age at the time of the original diagnosis of coeliac disease varied from 8 months to $8 \frac{1}{2}$ years. As a result of careful inquiry, all were considered to have adhered firmly to a gluten-free diet for periods of 4 to 10 years.

The diagnostic criteria were various: 20 had presented with diarrhoea and 3 with anaemia. In 16, a fat balance showed less than $90 \%$ absorption; in 4 , the faecal fat was more than $30 \%$, calculated as dried weight; in another 3, no tests of absorption were done, and the diagnosis was made on clinical grounds alone. None had had a jejunal biopsy.

For the purpose of the present study, each child was asked to discontinue the gluten-free diet, and to eat normal family meals. The period of deliberate dietary indiscretion varied from $2 \frac{1}{2}$ to 9 weeks with a mean of $5 \frac{1}{2}$ weeks. No measure was made of the quantity of gluten-containing foods eaten by each child.

Received November 8, 1967.
After an overnight fast, a biopsy specimen was taken. In 20 cases this was from the first loop of jejunum, in 3 cases it was from the distal duodenum. The technique has been described elsewhere (McNeish, 1967). All specimens were examined under a $\times 20$ hand lens, and then processed for routine histology.

In 17 specimens, disaccharidases were assayed in a mucosal homogenate (Dahlqvist, 1964).

\section{Results}

Two discrete groups emerged. In group I, comprising 17 children, the intestinal mucosa was clearly abnormal. A flat mucosal surface was found in 10 , while in 7 , ridges and convolutions were seen. Histologically, villous atrophy of moderate or severe degree was identified in each specimen, and a round cell infiltrate was prominent in all. Disaccharidase levels were estimated in 13 specimens, and all were much reduced (Table I).

In group II, comprising 6 children, finger or narrow leaf villi were seen. Histologically, each of these 6 jejunal biopsy specimens was within normal limits. Disaccharidase levels were measured in 4 specimens, and all were normal (Table I). Some clinical details of these patients in group II are summarized in Table II.

Of the 17 patients in group I, 3 developed mild diarrhoea while on their gluten-containing diet: 2 of these, as well as 2 others, lost up to $0.5 \mathrm{~kg}$. in weight when on this diet. There were no other complications.

Further progress. All the patients in group I were considered on histological grounds to have true coeliac disease. A gluten-free diet was restarted without difficulty in each case, and their clinical progress since has been satisfactory.

The 6 patients in group II were allowed to continue an ordinary diet, and they have now been followed for periods varying from 1 to $2 \frac{1}{2}$ years. All are well, without diarrhoea, anaemia, or radiological skeletal abnormalities. Serum iron and whole blood folate estimations have remained within normal limits. Each has at least maintained 
TABLE I

Mean Jejunal Disaccharidase Activities (range in parentheses)

\begin{tabular}{|c|c|c|c|c|c|c|}
\hline \multicolumn{4}{|c|}{ Subjects } & Lactase & Sucrase & Maltase (units) ${ }^{\star}$ \\
\hline $\begin{array}{l}\text { Group I (13 cases) } \\
\text { Group II ( } 4 \text { cases) } \\
20 \text { normal children } \\
45 \text { untreated coeliac }\end{array}$ & $\begin{array}{l}\cdots \\
\ldots \\
\cdots \\
\text { ildren }\end{array}$ & $\begin{array}{l}\cdots \\
\cdots \\
\cdots \\
\cdots\end{array}$ & $\begin{array}{l}\cdots \\
\cdots \\
\cdots \\
\cdots\end{array}$ & $\begin{array}{c}0 \cdot 48 \\
(0-1 \cdot 05) \\
5 \cdot 47 \\
(3 \cdot 24-8 \cdot 05) \\
4 \cdot 75 \\
(2 \cdot 30-8 \cdot 10) \\
0 \cdot 62 \\
(0-1 \cdot 85)\end{array}$ & $\begin{array}{c}1 \cdot 88 \\
(0 \cdot 56-3 \cdot 24) \\
7 \cdot 32 \\
(5 \cdot 00-11 \cdot 60) \\
6 \cdot 48 \\
(3 \cdot 70-11 \cdot 60) \\
1 \cdot 74 \\
(0 \cdot 11-4 \cdot 07)\end{array}$ & $\begin{array}{c}6 \cdot 85 \\
(1 \cdot 85-13 \cdot 89) \\
23 \cdot 29 \\
(15 \cdot 82-34 \cdot 80) \\
19 \cdot 93 \\
(12 \cdot 67-35 \cdot 56) \\
6 \cdot 68 \\
(1 \cdot 48-17 \cdot 04)\end{array}$ \\
\hline
\end{tabular}

$\star$ Units $=$ no. of micromoles of substrate split $/ \mathrm{min}$. per gram wet weight mucosa.

TABLE II

Some Clinical Details of Patients in Group II (non-coeliacs)

\begin{tabular}{|c|c|c|c|c|c|c|c|c|c|c|}
\hline \multirow{2}{*}{$\begin{array}{l}\text { Case } \\
\text { No. } \\
\\
1 \\
2 \\
3 \\
4\end{array}$} & \multirow{2}{*}{$\begin{array}{c}\text { Sex } \\
\text { F } \\
\text { M } \\
\text { F } \\
\text { F }\end{array}$} & \multirow{2}{*}{$\begin{array}{c}\begin{array}{c}\text { Age (yr.) } \\
\text { When } \\
\text { Diagnosed } \\
\text { as } \\
\text { Coeliac }\end{array} \\
10 / 12 \\
1 \\
13 / 12 \\
15 / 12\end{array}$} & \multicolumn{2}{|c|}{$\begin{array}{l}\text { Height }(\mathrm{H}) \text { and } \\
\text { Weight }(\mathrm{W}) \text { Centile } \\
\text { When Diagnosed } \\
\text { as Coeliac }\end{array}$} & \multirow{2}{*}{$\begin{array}{l}\begin{array}{c}\text { Duration of } \\
\text { Diarrhoea Before } \\
\text { Diagnosis }\end{array} \\
4 \text { wk. } \\
3 \text { wk. } \\
\text { Since birth } \\
6 \text { wk. }\end{array}$} & \multirow{2}{*}{$\begin{array}{c}\begin{array}{c}\text { Other } \\
\text { Symptoms }\end{array} \\
\overline{-} \\
\overline{-}\end{array}$} & \multirow{2}{*}{ 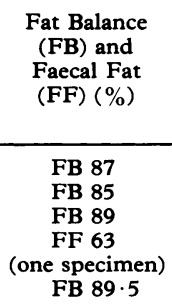 } & \multirow{2}{*}{$\begin{array}{c}\begin{array}{c}\text { Years on } \\
\text { Gluten- } \\
\text { free } \\
\text { Diet }\end{array} \\
45 / 12 \\
52 / 12 \\
5 \frac{1}{2} \\
5\end{array}$} & \multicolumn{2}{|c|}{$\begin{array}{c}\text { Height }(\mathrm{H}) \text { and } \\
\text { Weight }(\mathrm{W}) \text { Centile } \\
\text { After Gluten-free } \\
\text { Diet }\end{array}$} \\
\hline & & & $\begin{array}{c}3<\mathbf{H}<10 \\
\mathbf{H} 25 \\
\mathbf{H} 3 \\
\mathbf{H}<3 \\
\end{array}$ & $\begin{array}{l}\text { W3 } \\
\text { W10 } \\
\text { W3 } \\
\text { W }<3 \\
W<3\end{array}$ & & & & & $\begin{array}{l}\mathrm{H} 10 \\
\mathrm{H} 25 \\
\mathrm{H} 3 \\
\mathrm{H}<3\end{array}$ & $\begin{array}{c}\mathrm{W} 10 \\
25<\mathrm{W}<50 \\
W 10 \\
W<3 \\
W 3\end{array}$ \\
\hline 6 & $\mathbf{M}$ & $42 / 12$ & $\begin{array}{l}\mathbf{5 0}<\mathbf{H}<\mathbf{7 5} \\
\mathbf{2 5}<\mathbf{W}<\mathbf{5 0}\end{array}$ & $w<3$ & $\begin{array}{l}\text { Bouts of loose } \\
\text { stools with } \\
\text { mucus for } 2 \\
\text { yr. }\end{array}$ & $\begin{array}{l}\text { Serum iron } \\
10 \mu \mathrm{g} . \% \\
\text { Pica; } \mathrm{Hb} 60 \%\end{array}$ & FB 89.3 & $59 / 12$ & H50 & $25<W<50$ \\
\hline
\end{tabular}

the growth rate achieved on a gluten-free diet, while in 3 there has been an acceleration of growth over the follow-up period. No further intestinal biopsies have been taken.

\section{Discussion}

Bolt et al. (1964) emphasized that it was necessary for diagnostic purposes to obtain a jejunal biopsy specimen from each suspected coeliac patient before withdrawal of gluten, because the mucosal histology after treatment was sufficiently variable to make the diagnosis uncertain in some cases. Anderson (1960) had already shown that the mucosal lesion in childhood coeliac disease improves considerably on a gluten-free diet, and in some cases it returns completely to normal. This has also been the experience of the author.

It was for these reasons that an immediate jejunal biopsy was considered inadequate to confirm the diagnosis of coeliac disease in the patients in this study, and it was, therefore, felt justifiable to expose each child to a few weeks of gluten ingestion before obtaining a biopsy. Rubin and his colleagues induced mucosal atrophy in the ileum of adult coeliac volunteers by direct instillation of a slurry of high gluten wheat for 9 days (Rubin et al., 1962). A longer period of gluten ingestion was considered necessary in the present series in an attempt to avoid equivocal or early mucosal abnormalities, and also because no accurate time correlation existed between the artificial experiments of Rubin et al. and the ingestion of a normal gluten-containing diet. It may well be that a shorter period of gluten ingestion would have given similar results.

The differentiation of the two groups seems clear cut. Histologically, the mucosal specimens from group I were indistinguishable from those seen in untreated cases of coeliac disease. In the 13 cases where mucosal disaccharidases were measured, the results fell within the range defined for untreated coeliac disease (Table I).

The normal jejunal histology of all the patients in group II would seem to exclude the diagnosis of coeliac disease. In the 4 specimens in which disaccharidases were measured, the results were all 
within the normal range, and the value in 2 cases fell above the mean normal value (Table I).

The original diagnoses of the children in group II are unknown. None has any residual symptoms: there is evidence to suggest that the short stature in several may be constitutional. Cystic fibrosis has been excluded in each.

It could be argued that, to prove beyond all doubt that the histological abnormalities in group I were induced by gluten, a biopsy should have been obtained before as well as after the introduction of dietary gluten. Though small bowel biopsy in children can be safe and reliable (McNeish, 1967), each attempt involves admission to hospital and some inevitable discomfort. The present investigation was designed to minimize both of these. Moreover, the presence of severe villous atrophy in the small intestine of children indicates glutensensitive coeliac disease, the exceptions to this rule falling below the age-group of the present investigation (Burke, Kerry, and Anderson, 1965; Anderson, 1966).

\section{Summary}

A number of children have been found in whom the original diagnosis of coeliac disease was based on criteria now thought to be inadequate. All were still on a gluten-free diet.
The present investigation has shown that reintroduction of gluten for a few weeks, followed by jejunal biopsy, can clearly distinguish between coeliac and non-coeliac subjects.

It is a pleasure to thank Dr. R. A. Shanks for permission to study patients in his care, and for his encouragement and criticism, Dr. A. M. MacDonald and his staff for the histological reports, Drs. S. P. Rawson and E. M. Sweet for radiological assistance, and Professor H. G. Morgan and Dr. R. W. Logan for facilities in the laboratory.

\section{REFERENCES}

Anderson, C. M. (1960). Histological changes in the duodenal mucosa in coeliac disease: reversibility during treatment with a wheat gluten free diet. Arch. Dis. Childh., 35, 419.

(1966). Intestinal malabsorption in childhood. ibid., 41, 571.

Bolt, R. J., Parrish, J. A., French, A. B., and Pollard, H. M. (1964). Adult coeliac disease: histologic results of long-term low gluten diet. Ann. intern. Med., 60, 581.

Burke, V., Kerry, K. R., and Anderson, C. M. (1965). The relationship of dietary lactose to refractory diarrhoea in infancy. Aust. paediat. F., 1, 147.

Creamer, B. (1966). Coeliac thoughts. Gut, 7, 569.

Dahlqvist, A. (1964). Method for assay of intestinal disaccharidases. Analyt. Biochem., 7, 18.

Hubble, D. (1963). Diagnosis and management of coeliac disease in childhood. Brit. med. $\mathcal{F} ., 2,701$.

McNeish, A. S. (1967). Jejunal biopsy in infants and underweight children. Arch. Dis. Childh., 42, 623.

Rubin, C. E., Brandborg, L. L., Flick, A. L., Phelps, P., Parmentier, C., and Van Niel, S. (1962). Studies of celiac sprue. III. The effect of repeated wheat instillation into the proximal ileum of patients on a gluten free diet. Gastroenterology, 43, 621 . 